\title{
ALGAL DIVERSITY IN THE RICE FIELD OF PARSA DISTRICT (NEPAL)
}

\author{
Kiran Bala \\ Department of Botany, TU, Thakur Ram Multiple Campus, Birgunj, Nepal \\ Anil Kumar Sinha \\ Department of Botany, B.R.A. Bihar University, K.C.T.C. College, Raxaul, India \\ E-mail: kiran.mystry@gmail.com
}

\begin{abstract}
Twenty two species of algae were collected from rice field of Parsa district, Nepal and identified and recorded. Three Chlorophyceae, ten heterocystous cyanophceae and nine non-heterocystous cyanophyceae. Oscillatoria was most common in all the three selected rice field. Other species like Nostoc linkia, Anabaena oryzae and Merismopedia elegans have been also found as dominant taxa. Six cyanophyta and two chlorophyta are newly reported for Nepal.
\end{abstract}

\section{Key words}

Algal-diversity; rice field; parsa; species; cyanophyta

\section{Introduction}

Algae, an evolutionary point of view, are the origin of land plants and most ancient group of organism (Bhattacharya \& Medlin, 1998). Algae now a days, are exploited to tackle the major problems such as food, fuel, soil fertility, sanitation, pharmaceutical and health problems (Prasad, 2008)

Algae, especially cyanobacteria, contribute to fertility in the rice field of tropical as well as subtropical soils. Cyanobacteria are more dominant in soil of rice-field than sugarcane ones (Bongale, 1984). Presence of Nostoc calcicola is known to increase the carbon and Nitrogen level in saline sodic soil of rice field
(Sujatha et al., 1996).

Nepal is rich in algal flora and comprises 995 algal species (Prasad, 2011). The algal flora of rice field have been extensively investigated. Rice field algae of Jagranathpur and Pokharia (Prasad \& Prasad, 2001) were investigated earlier, but the rice field algae of Sirsiya, Bagahi and Vishwa were untouched. Therefore, in the present reaserch, primarily the distribution of algae in the rice field of Sirsiya, Bagahi and Vishwa were taken into consideration.

\section{Materials and methods}

Rice field of three distantly locations Sirsiya, 


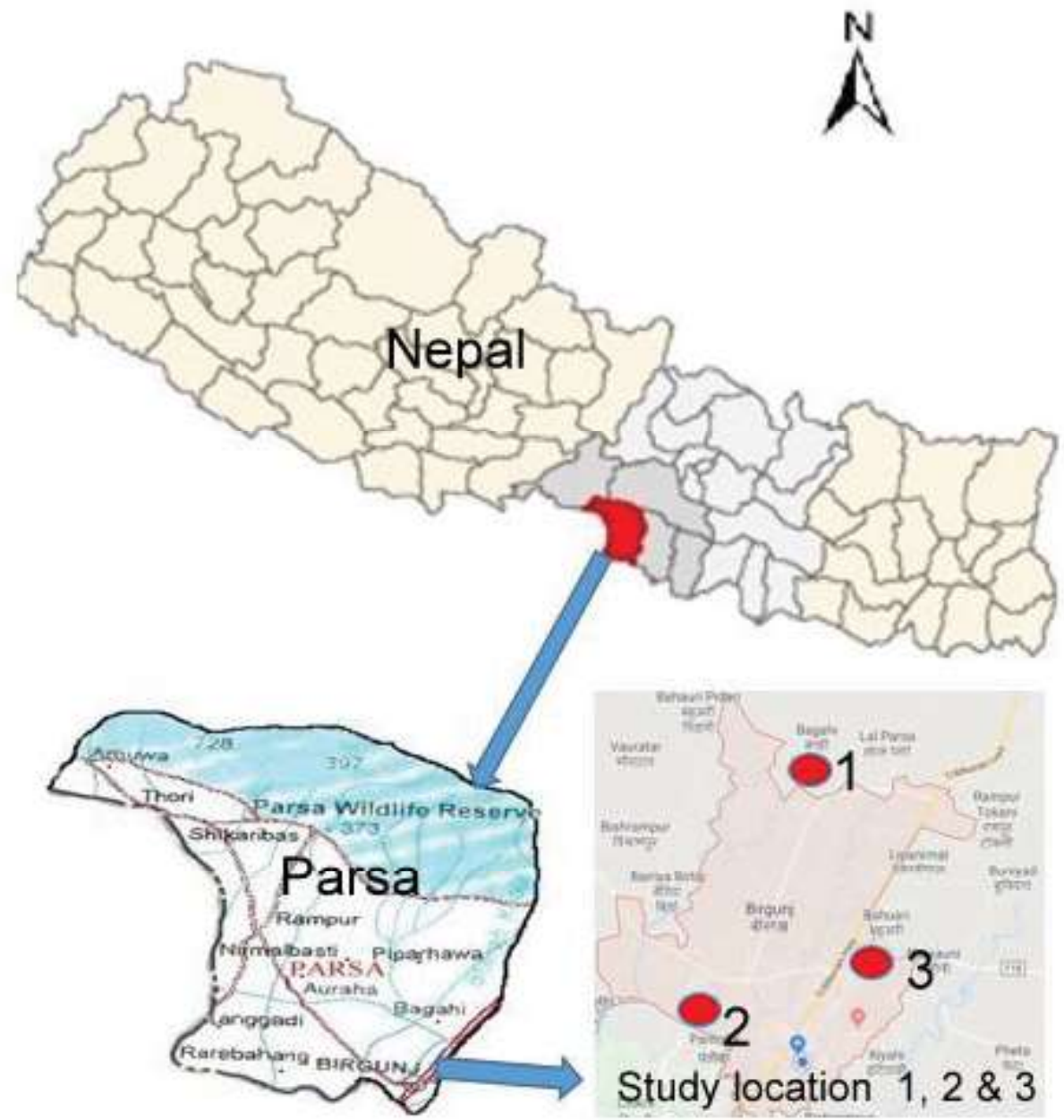

Fig. 1: Location map showing sites of samples collection

Bagahi and Vishwa in Parsa District (1353 sq. $\mathrm{km}$ ) having $24^{\circ} \mathrm{N}$ to $27^{\circ} 26^{\prime} \mathrm{N}$ - latitude $84^{\circ} 8^{\prime}$ E to $84^{\circ} 27^{\prime}$ E longitude were selected for the study. The temperature (2012-2013) in these fields ranged from $13.8{ }^{\circ} \mathrm{C}$ to $35.6{ }^{\circ} \mathrm{C}$ (Bala, 2006), pH varied from 6.1 to 6.7, the soil humidity was highest during September and lowest during May.

\section{Chemical nature of the soil}

The soil of the sampling sites fall under low categories for organic matter and total nitrogen content while $\mathrm{P}$ and $\mathrm{K}$ status of the soil was medium to low. However, $\mathrm{P}$ and $\mathrm{K}$ nutrition balance were found satisfactory for all the cropping system at all the sampling sites (Table 1).

Table 1: Soil analysis of Bagahi, Sirsiya and Vishwa

\begin{tabular}{|c|c|c|c|}
\multicolumn{1}{c}{ Sites } & $\mathrm{pH}$ & $\mathrm{Temp}\left({ }^{\circ} \mathrm{C}\right)$ & Humidity \\
Bagahi & $6.0-6.6$ & $15-32$ & $16-29$ \\
\hline Sirsiya & $6.1-6.6$ & $13-31$ & $16-26$ \\
\hline Vishwa & $6.3-6.6$ & $14-31$ & $16-26$ \\
\hline
\end{tabular}

\section{Analysis of Algal diversity}

The methods adopted for algal studies involved two steps-dry and wet conditions of rice field, to study the dormant algae soil 
samples irrigated with bristle inorganic nutrients solutions, (Nichols \& Bold,1965) and kept under laboratory condition for the algal emergence, but water logged rice field algae were directly observed under microscope, camera Lucida drawing were prepared. Identification was made with the help of Desikachary (1959), Presscott (1951) and Prasad (2011). Periodical variation in the soil temperature of different sampling zones is shown in Fig. 1.

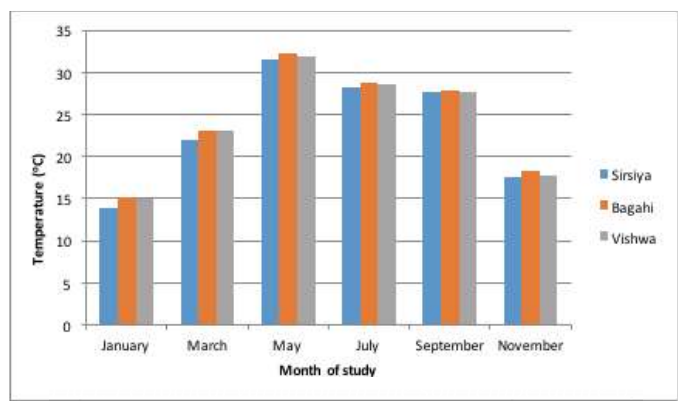

different sampling zones

\section{Taxonomical studies}

The data given in Table 2 shows distribution of algae in Birgunj. Taxonomical studies of these algae were done in the Department of Botany, Thakur Ram Multiple Campus, Birgunj.

Table 2: Distribution of Algae in Birgunj

\begin{tabular}{|c|c|c|c|c|}
\hline Name of Taxa & \multicolumn{3}{|c}{ Months } \\
\cline { 2 - 4 } & Jan & Mar & May Jul Sept Nov
\end{tabular}

Aphanocapsa ++++-+

biformis A Br.

Anabaena laxa ++++++

Bornet flah

*Anabaena oryzae ++++++

fritsch

\begin{tabular}{lllllll}
\hline A. variabilis kutz & + & - & - & - & - & - \\
\hline Arthrospira & - & + & - & - & + &
\end{tabular}

gomontiana

Setchell

Ankistrodesmus $+\quad+\quad-\quad-\quad-\quad+$

fractus brunnth

\begin{tabular}{|c|c|c|c|c|c|c|}
\hline \multirow{2}{*}{ Name of Taxa } & \multicolumn{6}{|c|}{ Months } \\
\hline & Jan & Mar & May & Jul & Sept & t Nov \\
\hline $\begin{array}{l}\text { *Chlorogloea } \\
\text { fritschiii Mitra }\end{array}$ & + & + & - & - & + & + \\
\hline $\begin{array}{l}\text { Gloeocapsa } \\
\text { decorticans rich }\end{array}$ & + & - & - & - & - & - \\
\hline $\begin{array}{l}\text { *Gloeotrichia } \\
\text { longicauda } \\
\text { Schmidle }\end{array}$ & + & - & - & - & - & + \\
\hline $\begin{array}{l}\text { Microcoleus } \\
\text { chthonoplastes } \\
\text { Thur }\end{array}$ & + & - & - & - & - & + \\
\hline $\begin{array}{l}\text { Microcystis } \\
\text { aeruginosa Kutz }\end{array}$ & + & - & - & + & - & + \\
\hline $\begin{array}{l}\text { Merismopedia } \\
\text { elegans A. Br. }\end{array}$ & + & + & + & + & + & + \\
\hline $\begin{array}{l}\text { Nostoc commune } \\
\text { Voncher }\end{array}$ & + & + & - & + & - & + \\
\hline $\begin{array}{l}\text { N. linckia Bornet } \\
\text { Flah }\end{array}$ & + & + & + & + & + & + \\
\hline $\begin{array}{l}\text { N. muscorum Ag. } \\
\text { Born }\end{array}$ & + & - & - & + & - & + \\
\hline $\begin{array}{l}\text { *Oscillatoria willei } \\
\text { Gardner }\end{array}$ & + & + & + & + & + & + \\
\hline O. Formosa Bory & + & + & + & + & + & + \\
\hline $\begin{array}{l}\text { *Oocystis } \\
\text { pyriformis prescoft }\end{array}$ & + & + & - & - & + & + \\
\hline $\begin{array}{l}\text { Synechosystis } \\
\text { aquatilis Sauv }\end{array}$ & + & + & + & + & + & + \\
\hline $\begin{array}{l}\text { *Scytonema } \\
\text { simplex Bhardwaja }\end{array}$ & + & - & - & + & + & + \\
\hline $\begin{array}{l}\text { *Scenedesmus } \\
\text { arcuatus G.M.Smith }\end{array}$ & - & + & + & + & + & - \\
\hline $\begin{array}{l}\text { *Westiellopsis } \\
\text { prolifica Janet }\end{array}$ & + & + & - & + & + & + \\
\hline $\begin{array}{l}\text { Total Number of } \\
\text { Taxa }\end{array}$ & 20 & 15 & 7 & 14 & 13 & 21 \\
\hline
\end{tabular}

\section{Cyanophyta}

Aphanocapsa biformis A. Brr.

Desikachary.Pt-21, P-10o. Thallus gelatinous; cells spherical loosely arranged; cells $4-7 \mu$ in diameter; $\mathbf{2}-4$ cells in a common mucilaginous envelope. 


\section{Anabaena laxa Rabenh.}

Trichomes straight, parallel with a mucilaginous sheath, cells spherical to barrel shaped, 5-6.5 $\mu$ long and 3.5-5.5 $\mu$ broad; end cells rounded; heterocyst spherical, $6.5 \mu$ broad or elongate upto $7.5 \mu$ long; spors single or many away from the heterocyst, $7-8 \mu$ broad and $14.20 \mu$ long.

Anabaena oryzae Fritsch.

Thallus gelatinous; trichomes short, straight and densely aggregated, cells barrel shaped 3-3.5 $\mu$ broad, heterocyst terminal or intercalary, $3.5-4.5 \mu$ broad, barrel shaped or spherical. (New to Nepal).

\section{Anabaena Variabilis Kutz.}

Thallus gelatinous, dark green; trichomes 3.5-6 $\mu$ broad, slightly constricted at cross walls; cells 3-6 $\mu$ long, barrel shaped, end cells concical; heterocyst spherical or oval $6.5 \mu$ in diameter; spores 7-9 $\mu$ broad and 8-13 $\mu$ long, not contiguous with the heterocyst.

\section{Arthrospira gomontiana Satchel.}

Trichomes regularly spirally coiled, pale-blue in colour attenuated at the apices, 2-3.5 $\mu$ Broad, cells 4-5 $\mu$ long.

\section{Chlorogloea fritschii Mitra.}

Thallus composed of rounded and irregular cell packets in the form of deep blue-green crust of indefinite size, without mucilage envelopes, cells 6-8 $\mu$ in diameter, endosporse spherical, $5-8 \mu$ in diameter. (Now to Nepal).

\section{Gloeocapsa decorticans (A. Br.) Richter.}

Cells spherical or oval, single or in a group of 2-4 blue-green in colour, single cells $22 \mu$ long, $18.5 \mu$ broad with sheaths; $8 \mu$ long and $6 \mu$ broad without sheath; in two celled stage, $28 \mu$ long and $22 \mu$ broad with sheaths and 12 $\mu$ long without sheaths.

\section{Gloeotrichia longicauda Schmidle.}

Thallus hemispherical; filaments radiating about 1mm long, sheath not lamellated, trichome gradually attenuated into a long hair, cells 5-8 $\mu$ broad; heterocyst of different sizes; spores ellipsoidal $15.5 \mu$ broad and 42.5 $\mu$ long. (Now to Nepal).

\section{Merismopedia elegans A. Braun.}

Colony irregular, quadra angular composed of many compactly arranged, ovate cells, cells 5-7.5 $\mu$ in diameter and 7-9 $\mu$ long.

Microcoleus chthonoplastes Th. Ex. Gomont.

Blue-green and lamellated thallus having many closely grouped trichomes; sheath transparent, uneven and thick; trichomes 2.4$4 \mu$ thick and constricted at the cross walls; cells $3-6.5 \mu$ in length; end cells pointed and conical.

\section{Microcystis aeruginosa Kutz.}

Young colonies round or slightly longer than broad; clatherate; cells spherical 3-7 $\mu$ in diameter.

Nostoc communae Voucher ex born Et. Flah.

Thallus firm, gelaterious; filament tangled, steath disterct; trichome 5-6 $\mu$ in broad; cells short barrel shaped to spherical, $5 \mu$ long; heterocyst spherical, $6.5 \mu$ in diameter.

Nostoc linckia (Roth) Bornet Ex. Born. Et Flah.

Thallus blue-green, filaments densely tangled, gelatinous; cells short barrel shaped, 3-4 $\mu$ broad and 2.5-4.5 $\mu$ long, heterocyst sub-spherical; $3.5-6 \mu$ broad and 3.5-6 $\mu$ long, akinetes 6-7 $\mu$ broad and 4.5-8 $\mu$ long.

Nostoc muscorum Ag. Ex. Born. Et Flah.

Thallus gelatinous-meneranous; filaments densely entangled, seath distinct at the periphery of the thallus, trichomes $5.5 \mu$ broad, cells barrel shaped to cylindrical, heterocyst spherical, 5.5-7.5 $\mu$ in diameter, 
spores ablong, many in chain, 4.5-8.5 $\mu$ broad and 7.5-11.5 $\mu$ long.

\section{Oscillatoria Formosa Bory ex. Gomont.}

Trichomes blue-green in colour, straight, slightly constricted at the cross walls, attenuated at the ends, cells $3.86 \mu$ broad, 3.5 $\mu$ long, end cells obtuse.

\section{Oscillatoria willei gradner em. Drouet.}

Trichomes pale blue-green in colour, bent at the ends, 2.5 to $4 \mu$ broad, 5-7 $\mu$ long, unconstricted at the cross walls. (New to Nepal).

\section{Scytonema simples Bhardwaja.}

Trichomes pale blue-green in colour, filaments 13-15 $\mu$ broad, loosely entagled false branched; sheath firm upto $2 \mu$ thick; trichomes with indistinct septa or with slight constrictions, 9-12 $\mu$ broad; cells usually elongate, cylindrical, heterocyst single or in pairs, cylindrical 9-12 $\mu$ broad and 11-40 $\mu$ long. (New to Nepal).

\section{Synechocystis aquatilis Sauv.}

Pale blue-green algae in clour, cells spherical, single or in two, 5-6 $\mu$ in diameter.

\section{Westiellopsis prolifica janet.}

Thallus filamentous with two kinds of branching, primary filament thicker and creeping having short barrel shaped cells, 8.5$13 \mu$ broad, secondary filament thinner growing erect, cells 4.5-6.5 $\mu$ broad and 8-11.5 $\mu$ long. Heterocyst intercalary in prostrate filaments spherical to oblong and in erect branches long cylindrical heterocyst diametrically same as the cells of the corresponding branches; pseudohormocyst present in erect branches, 8.5-9.5 $\mu$ in diameter. (New to Nepal).

\section{Chlorophyta}

\section{Ankistrodesmus fractus (West and West) Brunnthaler.}

Cells solitary, arched fusiform, the outerwall convex in the median portion only with almost straight wall extending to the sharply pointed apices. The inner margin concave in the median portion, straight towards the apices, cells $2.8 \mu$ in diameter, $40-43.5 \mu$ long.

\section{Oocystis pyriformis (Prescott)}

Cells broadly pyriform, ovoid with a prominent apiculation at one pole, the other end broadly rounded. Cells 14-16 $\mu$ in diameter, 16-19 $\mu$ long, colony of cells upto $36 \mu$ in diameter.

\section{Scenedesmus arcuatus (G.M. Smith)}

Cells arranged to form a curved, series of 4-16 $\mu$ oblong-ovate individuals with lateral walls in contact. Cell wall without spines or teeth, poles of the cell broadly rounded, cells 4-9 $\mu$ in diameter, 10-15 $\mu$ long. (New to Nepal).

\section{Discussion}

All together twenty two species belonging to seventeen genera have been recorded. Out of these three taxa of 3 genera belong to chloraphyta, ten taxa of nine genera belong to non-heterocystous cyanophyta and nine taxa of five genera belongs to heterocystous cyanophyta. November to January months were found most favourable for growth of all twenty one algal strains. Adhering to the variations in duration of their predominance following have been recognized.

(a) Having broader peak covering both rabi and kharif cropping seasons extending from july to march.

(b) Having narrow peak extending from July to September, corresponding with kharif.

(c) Having narrow peak extending from November to March, corresponding with rabi.

It has been concluded that the taxa, having braod peak bear broad range adaptability, (BRA). Out of twenty-two species, Anabaena oryzae, Oscillatoria willei, O.formosa, Nostoc linkia, Synchocystis aquatilis and 
Merismopedia elegans had been found dominant taxa, which is consistent with the work of Prasad and Prasad (2001) and Prasad (2005). Oscillatoria, Anabaena, Nostoc, were dominant in Parsa and was consistent with the work of Prasad (2006). This paper reports six new cyanophytes and two new chlorophytes.

\section{Acknowledgements}

I am very much thankful to Department of Botany, Thakur Ram Multiple Campus, Birgunj for providing me lab facility. I am also indebted to Dr. Umesh Prasad Shrivastawa, Associate Professor, Department of Botany, Thakur Ram Multiple Campus, Birgunj for his valuable guidance and suggestions.

\section{References}

Bala, K. (2006). Studies on the paddy field Algae of Birgunj (Nepal).

Baral, S. R. (1995). Enumeration of the Algae of Nepal: Biodiversity profile. Kathmandu: Technical publication no. 11, P.1-153.

Bongale, U.D. (1984). On the soil algae from paddy field of Panjim (Goa) and Chikkama chali (Raichur District, Karnataka). J. Indian Bot. Soc. 6o, 326.

Bhattacharya, D., \& Medlin, L. (1998). Algal phylogeny and the origin of land plants. Plant Physiology, 116(1), 9-15.

Das, S. N., \& Verma, B. N. (1996). Algal flroa of Chitwan and Nawalparasi districts of Nepal. Phykos 35 (1-2): 119, 127.
Desikachary T. V. (1959). Cyanophyta, Monograph.New Delhi; Indian Council of Agriculture Reasearch.

Nichols H. W. and Bold, H. C. (1965). Trichosarama polymorha gen. et. Sp. Nov. J. Phycol, 1:34-38.

Prasad, R. C. and Prasad B.N (2001): Screening of blue green algae and their distributional pattern in rice field of Narayani and Bagmati zone of Nepal.

Prasad, V. (2005): Algal and Cyanobacterial distruction in wheatfield of Bara, parsa and Rautahat Int. J, Mendel, 22(3-4):7778 .

Pant k, Prasad V and Gupta V.N.P (2006): Cyanobacterial diversity, J. Appl, Bnshu, 32(1):101-109.

Prasad V. (2006): Blue-green Algae of Birgunj, Nepal. J. Mandel, 23(3-4),125-126.

Prasad V. (2008). Algae Friends and Foes of Mankind. Nep. J. Dev. Rular Studies, 52, 106-111.

Prasad, V. (2011). Modem checklist of Algae of Nepal S. Devi (Manipal) pub. Birgunj, Nepal.

Prescott, G. W. (2005). Algae of the western Great lakes Area. Pub. Cran book institute of Science Michigan.

Sujatha, V. S. Raushik, B. D. \& Venkataranam, G. S. (1996). Agronomic potential of a marine cyanobacterium Nostoc calcicola. 